\title{
Destination Management and Imaging Kintamani towards Sustainable Tourism
}

\section{Ni Luh Putu Agustini K, I Made Sukarsa, Ni Wayan Sri Suprapti and Agung Suryawan Wiranatha}

\author{
School of Postgraduate Study \\ Doctorate Degree in Tourism Udayana University \\ Coressponding author: agustinikputu@gmail.com
}

\section{ARTICLE INFO}

Received

24 February 2014

Accepted

05 August 2014

Available online 10 September 2014

\section{ABSTRACT}

Kintamani destination has become a forerunner to the development of tourism in Bali. The last few years the brand Kintamani Destinations increasingly unpopular. This study aims to explain the paradigm shift and the role of management Kintamani Destinations in shaping the quality of service, image, satisfaction, and visitor's loyalty integrated manner affecting the sustainability of tourism. Management acts as a service provider consisting of stakeholders. Research on management aspects (supply side) has been implemented in the first phase qualitatively through depth interview. In stage II, conducted quantitative research on aspects of service quality, image, satisfaction and loyalty of visitors to Kintamani using SEM (Structural Equation Modeling). By accidental sampling questionnaire conducted to 250 tourists who visit Kintamani Destinations. Later in the third stage, verify the relationship of service quality, image, satisfaction, and loyalty to the sustainability of tourism in Kintamani through Focus Group Discussion (FGD). The findings of this research is the paradigm and the role of stakeholders in the destination management affects the quality of services provided in Kintamani. Aspects of quality of service, image, and satisfaction significantly affect the loyalty of tourists visiting Kintamani. The four aspects are directly determine the sustainability of tourism in Kintamani. The novelty of this research is both, from the aspect of supply and demand, destination management, service quality, imaging, and satisfaction rating affects loyalty, as well as an integrated manner affecting the sustainability of Kintamani tourism Destinations. These research results bring to all stakeholders that the management of destinations and image dominant influence on the sustainability of Kintamani Tourism Destinations. Thus, these aspects will be the focus of stakeholders in maintaining and developing Kintamani Tourism Destinations. Kintamani Destinations consider as a Tourist Destination Region Lodging (DTWK) with various constraints and limitations. The research on other aspects that critically affect the continuity of Kintamani Tourism Destination needs to be done further.

Keywords: destination management, service quality, imaging, satisfaction, loyalty, sustainable tourism.

\section{Introduction}

\section{Background}

Kintamani destination is known as a tourist attraction with a view of a very beautiful sunrise (Trip Advisor, 2014).
Activities of community-based tourism (CBT) dominant performed in Kintamani. Most of the tourism activity in this area involves the community, such as: climbing Mount Batur, Trunyan Cemetery, people trekking around in the plantation of Buahan Village, tourist 
bathing in natural hot water Toya Bungkah and agrotourism picking coffee, vegetables, as well as cultivation fish of Lake Batur.

Management involved includes governments, private businesses, local communities and tourism associations. All of them play a role as a stakeholder. The stakeholders have not been able to manage tourist attraction with the quality of service standards. Various complaints arise and weaken the image of Kintamani Destinations. Travelers who are not satisfied, will not visit again (disloyal) and would not recommend it to other travelers. This bad image impact on the decrease in the number of tourist visits.

Some research has been conducted in a variety of approaches in order to find solutions. It takes effort and management strategies of the fundamental aspects of a sustainable society in order to change the paradigm in providing services to tourists. Differences of interest in providing service, individual character, and differences in the acquisition of the benefits of tourism trigger social envy among fellow community tourism stakeholders. Uncontrolled resource eruption utilization, street vendors, anarchic action traveler fighting, bullying in Trunyan, all affect the image of Kintamani Destinations.

Considering various thorny issues arise in this destination, it is necessary to do research in a structured on every aspect that contributes to the sustainability of tourism and the local economy. It takes a special method of solving the gradual and systematic in analyzing this problem.

\section{Research Objectives}

The main objective of this study is to analyze the influence of management destinations, to the quality of service, image, tourist satisfaction, loyalty and sustainability of tourism in Kintamani. In more detail described as follows:

(1) To evaluate the paradigm and the role of stakeholders, in the management of tourism destinations in shaping the quality of service in Kintamani Destinations.
(2) To analyze the effect of service quality, image, satisfaction, to tourists' loyalty to Kintamani Destinations.

(3) To verify the relationship of service quality, image, satisfaction, and tourists loyalty to tourism sustainability in Kintamani Destinations.

\section{Literature Review}

\section{Previous Research}

Research of Ariana (2009), found that many irregularities behavior of local communities occur in providing services to tourists. Causes include: competition (scramble guests), does not have the skills in serving guests, there are no sanctions for such ill treatment, arrogant character, and the tendency of lazy learning in improving competence. Research of Agustini and Suarthana (2013), also found that the image of destinations with variable control WOM (Words of Mouth) significantly affects tourists to visit Kintamani Destinations. Research Agustini, Suarthana and Sutawa (2014) on community-based tourism in Trunyan, shows that it takes a synergy between stakeholders in the development of Trunyan. The research of Sudana and Mahadewi (2014) about Kintamani as a special interest tourist destination finds that it takes time to grow and build strategy implementation in the development of Kintamani Destinations.

\section{Concept and Theory of Management and Imaging}

Referral theories and concepts used in this study include: destination management theory Buhalis and Spada (2000); Caffyn and Jobbins (2003); Manente (2008); Tkaczynski, Rundle-Thiele and Beaumont (2008); Samah and Aref (2010); Saftić, Težak and Luk (2011). Theories and concepts of satisfaction, imaging, loyalty, referring to the theory of Grönroos (1984); Parasuraman, Zeithaml and Berry (1985); Baker and Crompton (2000); Hasan (2008); Anastassova (2011). At the final stage of the study visitors loyalty relationship with the sustainability of tourism in Kintamani refer to sustainable tourism theory Clarke (1997); McGettigan and Burns (2004); Jamrozy (2007); Alonso (2009). 


\section{Framework}

Based on the results of abstraction and synthesis of theory associated with the background of problems in Kintamani Destinations, then the frame of the study is described as Figure 3.1.

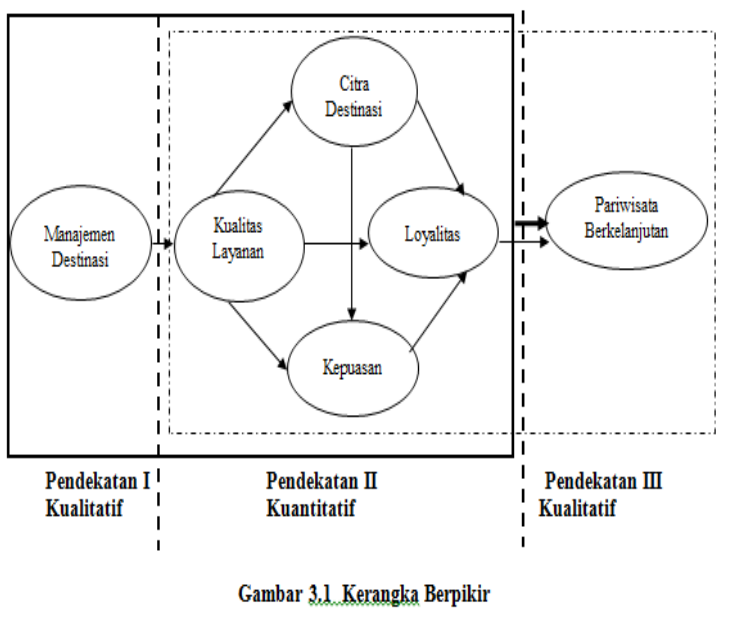

Stages of this research are determined based on a different perspective that is the perspective of supply (manager), consisting of stakeholders (government, communities, businesses, tourism associations) and the perspective of demand (tourists). This dissertation is divided into three stages. Phase I has been carried out to analyze Kintamani Destinations management aspects of the supply side, with a qualitative analysis techniques through in-depth interview; Phase II from the perspective of demand; analyzing aspects of service quality, imaging, satisfaction, and tourist loyalty to Kintamani Destinations. Quantitative analysis begins by distributing questionnaires to 250 tourists who visit Kintamani. The sampling is nonprobability sampling, with accidental sampling technique. The total respondents are 250 and from those who return the questionnaire, 231 data pertained valid, and 19 pertained invalid (outlayer). Quantitative research uses analytical tools SEM (Structural Equation Modeling). Phase III is analyzed qualitatively through FGD (Focus Group Discussion), in order to verify the relationship aspects in phase I and II to the sustainability of tourism in Kintamani Destinations.

\section{Hypotheses}

In the qualitative research phase one and three, there are not set hypotheses. Meanwhile, based framework and indicators of quantitative research, the hypothesis on phase two is set as follows:

Hypothesis H1: the quality of service positively and significantly influences the imagery Kintamani Destinations

Hypothesis H2: the quality of service positively and significantly influences the satisfaction of tourists to visit Kintamani Destinations.

Hypothesis H3: the quality of service, positively and significantly influences the tourist loyalty to visit Kintamani Destinations.

Hypothesis H4: destination image positively and significantly influences the satisfaction of tourists to Kintamani Destinations.

Hypothesis H5: destination image positively and significantly influences the tourist loyalty to visit Kintamani Destinations.

Hypothesis H6: tourist satisfaction positively and significantly influence tourist loyalty to visit Kintamani Destinations.

\section{Methodology}

\section{Population and sample}

The population is taken as a data source and can represent the entire population of the tourists visiting Kintamani. The number of tourists who were made respondents is as many as 250 people. While the key informant in-depth interviews and focus group consisted of 13 representatives of stakeholder Kintamani Destinations.

\section{Variable Research}

The variables at each stage of the study determined the appropriate approach to the supply side and demand side. Thus, the variables analyzed were classified into two, namely variables in qualitative research and 
quantitative research. Quantitative variables are shown in Table 4.1 below.

Tabel 4.1

Variabel Laten, Rujukan dan Indikator

\begin{tabular}{|c|c|c|c|}
\hline NO & LATEN & RUJUKAN & INDIKATOR \\
\hline 1 & $\begin{array}{l}\text { Variabel Eksogen } \\
\text { Kualitas layanan } \\
\text { (X1) }\end{array}$ & $\begin{array}{l}\text { Parasuraman et al. } \\
\text { (1985). }\end{array}$ & $\begin{array}{l}\text { 1) Lengkap (X1.1) } \\
\text { 2) Terjamin (X1.2) } \\
\text { 3) Cepat (X1.3) } \\
\text { 4) Akurat (X1.4) } \\
\text { 5) Responsif (X1.5) }\end{array}$ \\
\hline 2 & $\begin{array}{l}\text { Variabel Eksogen } \\
\text { Citra Destinasi } \\
\text { (X2) }\end{array}$ & $\begin{array}{l}\text { Pan dan } \mathrm{Li}(2010) \\
\mathrm{Li} \text { dan Voldesong } \\
(2011) .\end{array}$ & $\begin{array}{l}\text { 1) Promosi (X2.1) } \\
\text { 2) Media (X2.2) } \\
\text { 3) Komunikasi (X2.3) }\end{array}$ \\
\hline 3 & $\begin{array}{l}\text { Variabel eksogen } \\
\text { Kepuasan } \\
\text { (X3) }\end{array}$ & Kotler (2000). & $\begin{array}{l}\text { 1) Tarif (X3.1) } \\
\text { 2) Nilai (X3.2) } \\
\text { 3) Time Cost (X3.3) } \\
\text { 4) Psikologi (X3.4) }\end{array}$ \\
\hline 4 & $\begin{array}{l}\text { Variabel Endogen } \\
\text { Loyalitas } \\
\text { (Y) }\end{array}$ & $\begin{array}{l}\text { Rosen (2003) } \\
\text { Balter and Butman } \\
(2005) \text {. }\end{array}$ & $\begin{array}{l}\text { 1) Brand (Y1.1) } \\
\text { 2) WOM (Y1.2) } \\
\text { 3) Loyalitas (Y1.3) }\end{array}$ \\
\hline
\end{tabular}

Sumber: data diolah 2015

\section{Data Analysis}

Quantitative analysis uses AMOS Graphics Package 18 with SEM method. Qualitative analysis techniques in this study use a model of existential phenomenology and critical theory by the method of videotapes, interviews, and depth interview. Interviews and FGD reviews gradually based approaches appropriate concepts and theories. Referral research various parties are used as a benchmark for future studies corroborate the findings. Qualitative research method stages I and III are implemented in Kintamani Destinations applying qualitative research paradigm.

\section{Results and Discussion}

\section{Stakeholders in Management Paradigm Destinations}

The results of discussions at the first phase, with qualitative methods through deep interview conclude some of the followings:

1) The difference in the paradigm of stakeholders about the problems that occur in Kintamani Destinations cause differences in the solution strategy.

2) Differences in the paradigm of society in its role as stakeholders contribute causes protracted gap among stakeholders.
3) All stakeholders comprising government, communities, businesses, associations and other tourism players do not play a role in a balanced way in the management of tourist attraction Kintamani.

4) It takes synergy, coordination and collaboration among stakeholders in order to carry out managerial functions properly and professionally

Referring destination management theory and the concept of stakeholders from Buhalis (2000); Caffyn and Jobbins (2003); Manente (2008); Tkaczynski, Rundle-Thiele and Beaumont (2008); Samah and Aref (2010); Saftić, Težak and Luk (2011) showed that paradigm and the role of stakeholders in the destination management largely determines the quality of services provided in Kintamani.

The Influence of service quality, image, satisfaction and Loyalty of tourists to Kintamani Destinations

Based on the analysis using SEM, further is described the meaning of the results more deeply and applicably. Referring to the hypotheses that have been determined, then the translation of the SEM results on the effect of service quality, image, satisfaction and loyalty tourists to visit Kintamani Destinations is shown in Figure 1 below.

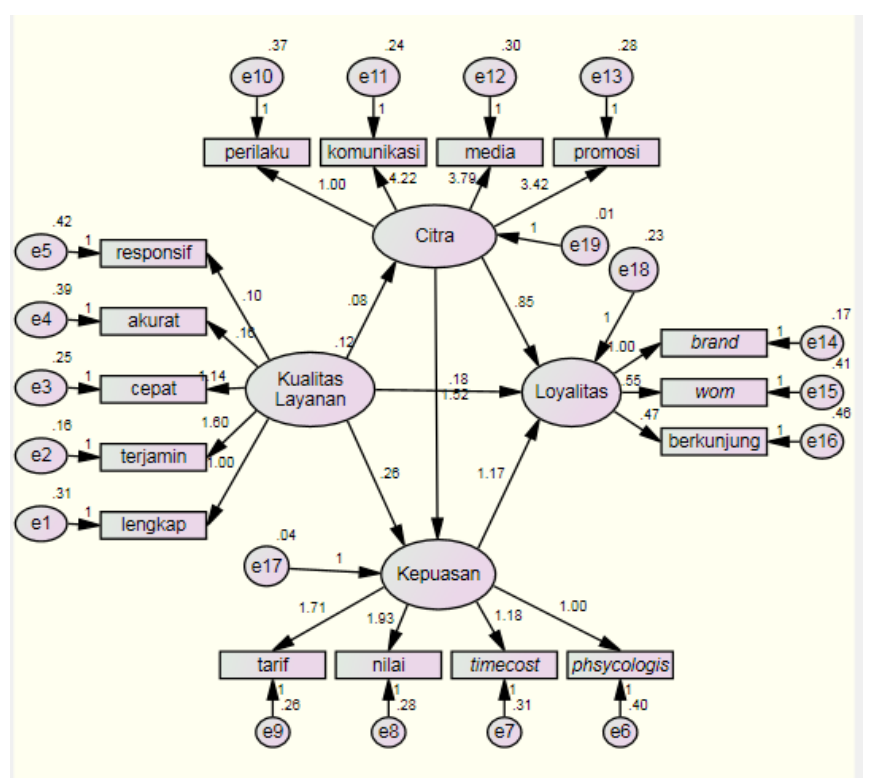

Figure 1. Structural Modeling 
Kintamani Destinations research hypothesis testing is done by using SEM. The acceptance on testing the hypothesis is whether an estimated value can refer to the determination of value ( $p$ value $\leq 0.05$ ). The result of hypothesis testing shows the effect of quality of service, image, tourist satisfaction and loyalty can be described in Table 5.1 .

Tabel 5.1

Hasil Pengujian Hipotesis Model Struktural

\begin{tabular}{|c|l|c|c|c|c|}
\hline Hipotesis & \multicolumn{1}{|c|}{ Arah Jalur } & $\begin{array}{l}\text { Koefisien } \\
\text { Regressi }\end{array}$ & C.R & p-value & $\begin{array}{c}\text { Koefisien } \\
\text { Baku }\end{array}$ \\
\hline H1 & $\begin{array}{l}\text { Kualitas layanan } \\
\text { Citra }\end{array}$ & 0,085 & 1,497 & 0,134 & 0,340 \\
\hline H2 & $\begin{array}{l}\text { Kualitas layanan } \\
\text { kepuasan }\end{array}$ & 0,261 & 2,841 & 0,004 & 0,340 \\
\hline H3 & $\begin{array}{l}\text { Kualitas layanan } \rightarrow \\
\text { loyalitas }\end{array}$ & 0,177 & 0,960 & 0,337 & 0,099 \\
\hline H4 & Citra $\rightarrow$ kepuasan & 1,524 & 1,533 & 0,125 & 0,496 \\
\hline H5 & Citra $\rightarrow$ loyalitas & 0,852 & 0,758 & 0,448 & 0,118 \\
\hline H6 & Kepuasan $\rightarrow$ loyalitas & 1,175 & 2,899 & 0,004 & 0,502 \\
\hline
\end{tabular}

Sumber: data diolah 2015

Based on the results of the testing of the structural model in Table 5.1, the hypothesis can be summarized as follows:

1) The relationship between variables of service quality and the image of the destination. Variable quality of service (X1) has no significant effect towards the variable destination image (X2) with a pvalue equals to (0.134). It can be concluded that the quality of services provided in Kintamani Destinations does not significantly affect the image.

2) The relationship between variable of service quality and satisfaction of tourists. Variable quality of service (X1) significantly influences traveler satisfaction variables (X3), with a p-value equals to (0.004). It can be concluded that there is a significant effect of the quality of service towards the satisfaction of tourists visiting Kintamani Destinations.

3) The relationship between variables of service quality and the loyalty of tourists. Variable quality of service (X1) has no significant effect towards tourist loyalty variable (Y1) with a p-value equals to (0.337). It can be concluded that the service quality loyalty does not have a significant effect towards tourists visiting Kintamani Destinations .
4) The relationship between the images of tourist satisfaction and variables. Variable image (X2) has no significant effect towards satisfaction variable (X3), with a p-value equals to (0.125). It can be concluded that the destination image has no significant effect towards tourist satisfaction to Kintamani Destinations .

5) The relationship between the images and the variable of traveler loyalty.Variable destination image (X2) has no significant effect towards loyalty variable (Y1), with a p-value equals to (0.448). It can be concluded that the destination image ha no significant effect towards tourist loyalty to Kintamani Destinations .

6) The relationship between variables of tourist satisfaction and loyalty. Satisfaction variable (X3) significantly affects the loyalty variable (Y1), with a pvalue equals to (0.004). It can be concluded That traveler satisfaction significantly influences traveler loyalty visiting Kintamani Destinations.

\section{The Influence of Model on Image Quality of Service, Satisfaction and Loyalty of Traveler}

The results of direct assessment of the respondents to the variable quality of service, image, satisfaction, and loyalty are at a highenough score that is above (3.6). According to Likert Scale, a score is assigned from a scale of 1 to 5 . This shows that the indicators presented in the questionnaire study was considered quite relevant and positive as the reflection of the quality of service, image, satisfaction, and loyalty of tourists to Kintamani Destinations.

Furthermore, the results of the analysis using SEM show that the effect of quality of service, image, and satisfaction shows a positive result to the loyalty of tourists to Kintamani Destination. Description of the model analysis results of this study can be illustrated in Figure 5.2 as follows. 


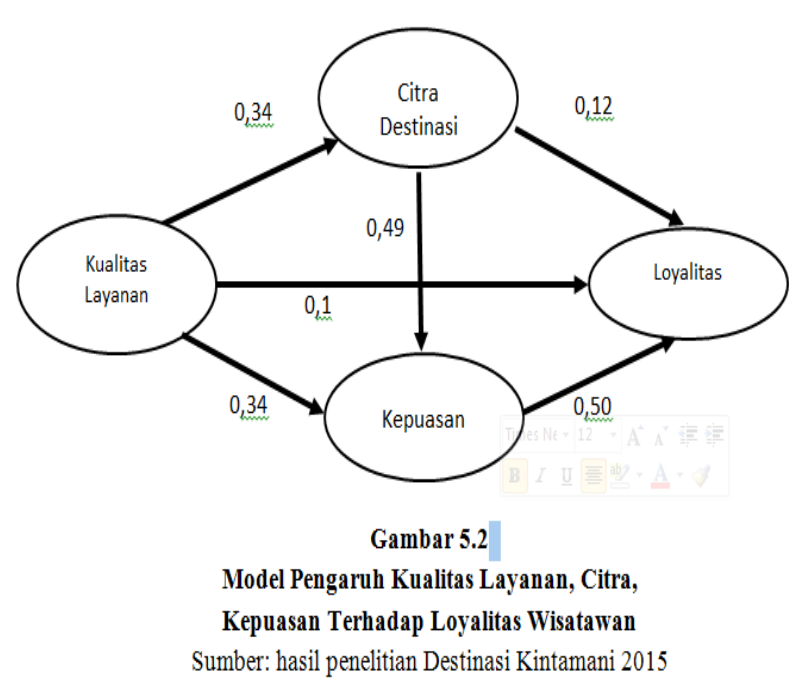

Based on the results of the model analysis using SEM in Figure 5.2 it is clearly visible that the variables affect service quality by 34 percent against the image, but not significant ( $\mathrm{p}$-value $>0.05$ ). Variable service quality does by 34 percent against the tourists' satisfaction and is significant ( $p$-value <0.05). Variable quality of service only affects 10 percent of the loyalty but not significant ( $p$-value> 0.05 ). The Variables affect the image by 49 percent on tourist satisfaction but not significant ( $\mathrm{p}$ value> 0.05). Variable destination image influences by 12 percent on the tourists loyalty but not significant (p-value> 0.05). The highest satisfaction variables affect by 50 percent and give significant impact on loyalty and it is significant ( $\mathrm{p}$-value $<0.05$ ).

The results provide justification to the stakeholders involved in the management of Kintamani Destinations that the quality of service, image and satisfaction to tourists visiting Kintamani Destinations determine the travelers' loyalty. Governments, employers, communities, associations, NGOs as stakeholders together should give priority to the aspects of quality of service, imaging, and retain tourists visiting guaranteed satisfaction. If these three aspects are met, then the travelers' loyalty to Kintamani Destinations will be realized.

Quality of service with all the indicators, the image formed by the indicator promotion, media, communications, and traveler satisfaction should be a priority to be improved, in order to achieve loyal travelers. Stakeholders should pursue promotional http://ojs.unud.ac.id/index.php/eot activities, media publications, facilitate communication with travelers and provide training behavior (attitude, manners and courtesy) good in serving tourists. Provision of intensive coaching and counseling to community tourism players are slowly but surely will change the old paradigm to the new paradigm. Community orientation is an excellent service, not just to earn a moment. Good service is an important indicator that determines travelers' satisfaction. At the time of satisfied travelers, with easy access to Kintamani Destinations, the relevant rates, that travel time is short and psychological comfort are met, and then the hope for them to come back even becomes high.

As the core driver management Kintamani Destinations, the government should renew the website, utilize print, electronic, social media, and increase the marketing budget. Empowerment of communities, implement effective training and strengthen regulation in order to improve the quality of service, image and tourist satisfaction. According to the theory, if the tourists are satisfied they would re-purchase or visit again and if they become loyal they would recommend Kintamani to other colleagues.

\section{Limitations of the research}

This study examines the various aspects that affect the management and image Kintamani Destinations towards sustainable tourism. In its application, the research results show that some specific characteristics of the region should be put as an important consideration. DTWK status with the structure of the soil, geological conditions of the environment, and that the discharge of the water of the lake is not stable, and the status of Mount Batur that is still active, make this area very limited to be developed.

On the other hand, the character of the local community in Kintamani Destinations are very specific, somewhat harder and less friendly, while it has a natural appeal unique and fascinating for tourists. Varieties of nature-based tourism activities and culture involving local communities make both of these things come into a dilemma, but require foresight researchers to study aspects that 
allow the development of this region for the better. Further research should pay attention to the specific characteristics of the region, and make the critical aspects of this as a reference in formulating problems and give advice on the research findings.

\section{Conclusion and Recommendation}

\section{Conclusion}

Referring to destination management theory, the theory of imaging, quality of service, satisfaction and sustainability of tourism, the conclusions of this study are:

1. Roles and stakeholders in the destination management paradigm affect the quality of services provided in Kintamani.

2. Aspects of quality of service, image, and loyalty affect tourist satisfaction positively and significantly to visit Kintamani.

3. Quality of service, destination image, satisfaction, and tourists' loyalty to Kintamani affect the sustainability of tourism.

\section{Recommendation}

1. It is necessary academically to conduct further research on destination management more broadly with indicators that are more complete. Application of the concept of quality of service, imaging, standard analysis traveler satisfaction, and loyalty to their overall needs need more in-depth assessment. Other aspects that have to do with these variables must be taken into consideration in future research.

2. In its application stakeholders strongly support the development of tourism destinations. Kintamani Destinations become a mainstay of the world. But the character of the people, the condition of natural resources and human resources are still low. The ability of stakeholders in the governance of destinations, competence of stakeholders in creating quality services, imaging, and creating the satisfaction of tourists still need to be improved. Improvement in these areas will ensure the loyalty of tourists.

3. Stakeholders must make loyalty rating as a priority because their loyalty is a

http://ojs.unud.ac.id/index.php/eot guarantee of the sustainability of tourism in Kintamani Destinations. Utilization of information and technology, social media and the entire facility which can improve performance of Kintamani Destinations must be the focus of attention of stakeholders.

\section{References}

Agustini, N. L. P. and Suarthana, I. K. P. (2013) 'How Does Destination Management Organization (DMO) Increase Local People Participation?', in Proceeding AITTEI 2nd Conference. Malaysia.

Agustini, N. L. P., Suarthana, I. K. P. and Sutawa, G. K. (2014) 'Challenges and Barriers in Community Base Tourism In Trunyan Village, Kintamani', in Proceeding Tourism in Indonesia. Bali.

Alonso, A. D. (2009) 'Are travellers interested in wine tourism in New Zealand?', International Journal of Culture, Tourism and Hospitality Research. Emerald Group Publishing Limited, 3(1), pp. 13-24.

Anastassova, L. (2011) 'Tourist loyalty and destination brand image perception: the case of Sunny beach resort, Bulgaria', European journal of tourism research. Varna University of Management, 4(2), p. 191.

Ariana, I. N. (2009) 'Patologi Sosial dalam Pariwisata: Pelaku Sektor Informal dan Citra Pariwisata Kintamani', Jurnal Analisis Pariwisata I Volume 9 No 1, p 7-14. Udayana University.

Baker, D. A. and Crompton, J. L. (2000) 'Quality, satisfaction and behavioral intentions', Annals of tourism research. Elsevier, 27(3), pp. 785804.

Buhalis, D. (2000) 'Marketing the competitive destination of the future', Tourism management. Elsevier, 21(1), pp. 97-116. 
Buhalis, D. and Spada, A. (2000) 'Destination Management of Rural Tourism', Journal Destination Management Systems: Criteria for success, Information Technology \& Tourism, 3(1).

Caffyn, A. and Jobbins, G. (2003) 'Governance capacity and stakeholder interactions in the development and management of coastal tourism: examples from Morocco and Tunisia', Journal of Sustainable Tourism. Taylor \& Francis, 11(2-3), pp. 224-245.

Clarke, J. (1997) 'A framework of approaches to sustainable tourism', Journal of sustainable tourism. Taylor \& Francis, 5(3), pp. 224-233.

Grönroos, C. (1984) 'A service quality model and its marketing implications', European Journal of marketing. MCB UP Ltd, 18(4), pp. 36-44.

Hasan, A. (2008) 'Marketing Edisi ke 1', Media Pressindo: Yogyakarta.

Jamrozy, U. (2007) 'Marketing of tourism: a paradigm shift toward sustainability', International Journal of Culture, Tourism and Hospitality Research. Emerald Group Publishing Limited, 1(2), pp. 117-130.

Manente, M. (2008) 'Destination Management and Economic Background: Defining and Moni-toring Local Tourist Destinations', in International Conference Measuring Tourism Economic Con-tribution at Subnational Levels, Malaga, Hiszpania, pp. 29-31.

McGettigan, F. and Burns, K. (2004) 'Community Tourism Research in Kiltimagh 2003/04', in Quality of Life Á/Competing Value Perspectives in Leisure and Tourism, ATLAS Conference Leeuwarden, The Netherlands, 19Á/21 June.
Parasuraman, A., Zeithaml, V. A. and Berry, L. L. (1985) 'A conceptual model of service quality and its implications for future research', the Journal of Marketing. JSTOR, pp. 41-50.

Saftić, D., Težak, A. and Luk, N. (2011) 'Stakeholder approach in tourism management: implication in Croatian tourism', in 30th International Conference on Organizational Science Development-FUTURE ORGANIZATION.

Samah, A. A. and Aref, F. (2010) 'People's Participation in Community Development: A Case Study in a Planned Village Settlement in Malaysia'. Putra University, Malaysia.

Sudana, I. P. and Mahadewi, N. P. E. (2014) 'Strategi Pengembangan Pariwisata Minat Khusus di Kawasan Pariwisata Kintamani Kabupaten Bangli', Jurnal Perhotelan dan Pariwisata, 4(2).

Tkaczynski, A., Rundle-Thiele, S. R. and Beaumont, N. (2008) 'Insights into how regional tourism operators view their markets', International Journal of Organisational Behaviour. University of Southern Queensland, 13(1), pp. 16-27. 